\title{
Matrimonial Property and Legality of claiming it Between Fiqh and the Laws of Malaysia, Morocco and Tunisia
}

\author{
Mohamed Shafei Moftah Bosheya \\ Universiti Islam Antarabangsa Sultan Abdul Halim Mu'adzam Shah (UniSHAMS), \\ Kuala Ketil, Kedah, Malaysia
}

\begin{abstract}
One of the most important goals of the marital relationship is the affection and compassion that drive spouses to cooperate together in earning their livelihood. When the marital relationship breaks down, each of the spouses would claim his/her share of the matrimonial property; such claim is different from the stipulated legal dues such as the inheritance and the alimony. The question is, what is the definition of the matrimonial property? Does this concept exist in the old Islamic jurisprudence? Is it legal to claim this money by one of the spouses or their heirs? And to what extent is the interest achieved or hardship avoided if the claimant is given his/her share? What is the position of the Malaysian Judiciary and its legal text on that issue? What is the stand of the official fatwa departments on this issue? What are the types of legal evidence cited by the different fatwas related to the matrimonial property? Moreover, are there countries other than Malaysia that have adopted this system?
\end{abstract}

Keywords---fatwa, jointly-shared property, judiciary, jurisprudence, marital life.

\section{Introduction}

\section{Definition of jointly shard property (Al-Māl Al-Mushtarak) and its categories}

\section{Definition of Al-Māl Al-Mushtarak:}

Al-Māl is "whatever possession owned by an individual or a group, including properties, goods, business, real estate, cash or animals" (Academy of the Arabic Language in Cairo, D. T. The Intermediate Lexicon:2/892)

Generally speaking, the term "Al-Māl Al-Mushtarak" is an old term; it is mentioned in some chapters of figh works without singling out the matrimonial property except for Al-Imam Al-Haskafi, who mentioned the differences among the

Linguistics and Culture Review (c) 2021.

Corresponding author: Bosheya, M.S.M.; Email: shafeimoftah@unishams.edu.my

Manuscript submitted: 09 July 2021, Manuscript revised: 18 Oct 2021, Accepted for publication: 27 Nov 2021 
madhhab scholar about the division of the revenues of the spouses' joint business:

"If the business of the husband and wife yielded large fortunes, some scholars argued that the money belongs to the husband, and the wife is deemed his assistance, except if she has separate business; in such a case, the earnings of the separate business are hers. On the other hand, some scholars maintain that the money should be divided evenly among the spouses." (Al-Hasakfi.2002. Al-Dar Al-Mukhtar: 4/325)

However, some researchers deem it an emergent issue (nāzilah) in some Southeast Asia countries, especially Malaysia (Mohamed Shahed.2016. Majallat Sl-Shariah Wal Qanoon. Malaysia. Vol 3. 5)

\section{Matrimonial property in Malaysian law}

Marital property is called "harta sepencarian" in Malaysia; it has various definitions including:

- "The property acquired by the spouses during an established marriage, whose conditions are fulfilled according to the Shar'i rule" (Mohamed Shahed. 2016.Vol 3. 6). This definition focuses on the wealth acquired by the spouses during marriage, but not the money gained through inheritance by each or both of them.

- "The property acquired during the spouses' marriage as a result of their joint resources or efforts" (Ibid).

- "The property acquired after marriage that both spouses participate in earning and developing, whether their contribution is direct or indirect" (Ibid).

\section{Categories of the matrimonial property:}

In my opinion, this type of property can be divided into four categories:

- Monthly salaries of employed spouses.

- Profits of the spouse's joint business.

- Income of private works, like lectures, lessons and professions that the spouses practise jointly or separately.

- Wealth increases resulting from the private property owned separately by each spouse.

These four categories differ from a case to case in terms of their ownership proofs, amounts and types of evidence submitted to court.

\section{Wife's claim of her share in the matrimonial property between fiqh and law}

Some scholars and muftis in Malaysia and other countries hold that a divorced wife or a wife whose husband has passed away has the right to get her share of the matrimonial property being a contributor to it and for the following reasons: 
First: the broad meaning of the verse: "For men is a share of what they have earned, and for women is a share of what they have earned." (Al-Nisā' 04:32). The verse generally indicates that each spouse has a share in the earnings (Fisher \& Geiselman, 2010). Although this generality argument was not mentioned by classic exegetes, there is nothing to rule out using it (Ho, 2014). In fact, the personal status law legislator and muftis in Malaysia have adopted this generality argument (Harta Sepencarian, Mohamed Shahed.2016.Vol 3. 8,10.kelantan.jksm.gov.my).

Second: The 'urf principle, "a custom is legally authoritative) Al-'âdatu Muhakkamah)" is applied regarding the division of the matrimonial property between the spouses since it has been the custom practiced in the Malaysian society for years without any harm; in fact, its application has brought about social benefits (Ibid).

Third: al-mașlahah al-mursalah (public interest). Although al-maslahah almursalah is a disputed law source, it is still valid evidence that goes in line with the Shari'ah objectives (Oprisan \& Cristea, 2012; Panisoara \& Serban, 2013; Onat $\&$ Beji, 2012). Scholars depended on this evidence in the division of the matrimonial property among the spouses which realizes benefits for the woman such as protecting her after separation from impoverishment, helping her to start a new life where she can raise her kids after husband's death or divorce and preventing injustice towards her if her husband has a second marriage (Kawalek, 2020; Mikhail, 2009). All in all, the division of the matrimonial property brings about the wife's interest and doesn't cause any harm to the spouses (Mohamed Shahed. 2016.Vol 3. 10).

Based on the above proofs and others, fatwas have been issued confirming this right, provided that the Shari'ah guidelines are followed. Among these fatwas are:

\section{A decision of the Scholars of the Kelantan State Islamic Religious and Malay Customs Council (MAIK) in August 2002, Malaysia:}

The decision stated that the wife has the right to claim her share in the matrimonial property after separation from her husband through death or divorce. This right is also established for her heirs in case of her death.

2. A fatwa issued by the Fatwa Committee of Selangor, Malaysia, states the following:

It is lawful to divide the matrimonial property before distributing the spouse's inheritance. Such division is to be proportionate to the contribution of each spouse and to be conducted by the court (Fatwa Tentang Harta Sepencarian Selepas - Jild:58 No 13-23HB Jun 2005).

\section{Fatwa of some Moroccan scholars:}

The matrimonial property is handled according to the lawsuit's procedures in terms of the standards of evidence and oaths; if that is difficult, then the reconciliation rules are applied with the spouses' agreement.

Based on the above, it is clear that the matrimonial property ruling is based on inference from the Qur'an, reference to a fiqhi maxim and the application of almaslahah al-mursalah. The fatwas based on these proofs seek to achieve the 
interests of the spouses while abiding by the Shari'ah guidelines and following the proper and recognized fiqhi and legal standards of evidence (Ainslie, 2015).

The matrimonial property and claiming it in light of the Malaysian, Moroccan, and Tunisian Laws

\section{First: The Malaysian Law}

Following are the most important aspects related to the matrimonial property in the Malaysian Law:

\section{The right to claim the matrimonial property and its basis}

a) The matrimonial property has been codified as one of the elements of wealth distribution in all Malaysian states based on Shar'i, customary and social grounds.

b) The Malaysian people have applied this right and division in cases of death and divorce for long years which has been deemed a legal basis to recognize it.

c) There is no proof that this system has caused any harm to the Malaysian society; all related court cases have been judged in favor of the claimant (Mohamed Shahed. 2016.Vol 3. 6,7,10).

d) Malaysian courts treat fixed, movable, visible and hidden assets equally; all these types are considered matrimonial property and court decisions are made accordingly as long as the funds are not officially assigned to one of the spouses (Mohamed Shahed. 2016.Vol 3. 5).

\section{Procedures of claiming the matrimonial property}

The Malaysian Law grants the right to claim the matrimonial property following the steps below:

a) The right to claim the matrimonial property is established for both the husband and the wife.

b) It is necessary to refer to the Shar'i court in the local states.

c) The Shar'i court has the jurisdiction to issue the decision of property division after the marriage termination.

d) The court has the power to offer any notes or directions to the spouses before the division decision.

e) The claimant must confirm the validity of the marriage and its registration in the local administration of religious affairs according to the law.

f) It is mandatory to produce evidence and testimonies that the property was in the spouses' possession during the marriage period and that the claimant has contributed to it.

\section{The way of dividing the matrimonial property among the spouses}

a. There is no clear legal provision that specifies the share of the claimant of the matrimonial property; it is left to the discretion of the court. However, according to a number of cases, the share ranges from one third to half of the husband's wealth (Mohamed Shahed. 2016.Vol 3,10).

b. Distinction is made between cases according to whether there are children of the marriage or not. In the former case, the division needs to be discussed with all the beneficiaries. On the other hand, if there are no children, the property goes to the wife; the same applies in case of the husband's death (Harta Sepencarian.kelantan.jksm.gov.my).

c. The property is divided after settling all the spouse's debts. 
d. The reason for divorce has no effect on the wife's entitlement to her share of the property, even if she is divorced due to committing adultery according to the Kelantan State Court (Ibid).

\section{Comment on the Malaysian law's position on the matrimonial property}

The law provisions and the practice of courts regarding matrimonial property conform to some texts, general principles and law sources of the Shari'ah. However, the Malaysian law articles regulating the matrimonial property need to be reviewed thoroughly and be corroborated with Shari'ah-compliant items. In addition, any articles conflicting with the Shari'ah need to be removed (Sobko et al., 2021).

\section{The Moroccan law}

Article 49 of the Family Code stipulates the matrimonial property regulations and the way of dividing it (Ministry of Judgment. Morocco. 2016.Family's Blog.20). The matrimonial property has several names, the most famous of which is "Haqq alKadd wa al-Si'ayah" which is defined as "a personal right entitled by the contributions of partners in a customary company to develop or create the family wealth; in return for that, they are entitled to part of the revenue that is proportionate to the amount of their contribution estimated at the time of property division (Suryasa, 2019). All the above is conducted according to the requirements and rules of the local custom" (https://www.mohamah.net/law).

The Moroccan law stipulates a number of regulations; in summary, it considers the money created or acquired during marriage as shared between the two spouses; accordingly, each of them has the right to claim his/her share from the other spouse when the marriage is terminated (Sudama, 2020). The law stipulates also that each spouse has the right to make an agreement that manages and distributes the duties and gains among the spouses in a way that protects the rights of both of them; the more independent this agreement is from the marriage contract the stronger. If the agreement is not written the whole issue is decided according to the general standards of evidence. (Muzkaldy,Omar. Management of money earned between spouses. marocdroit.com).

Article 49 stipulates that "Each of the two spouses has an estate separate from the other. However, the two spouses may, under the framework of the management of assets to be acquired during the marriage, agree on their investment and distribution." It adds, "In the absence of such an agreement, recourse is made to general standards of evidence, while taking into consideration the work of each spouse, the efforts made as well as the responsibilities assumed in the development of the family assets" .(Ministry of Judgment. Morocco. 2016.Family's Blog.20).

What affirms the necessity of a prior agreement between the spouses regarding the joint responsibilities and shared properties and their division is the Moroccan Court of Cassation's decision number 312 on April 22, 2014 that it is necessary to prove the existence of a prior agreement between the spouses that indicates 
their contribution to the property to make it possible to divide the matrimonial property among them (https://www.lejuriste.ma.2017).

\section{Comment and comparison}

The Moroccan law widens the scope of this right to include not only the spouses but also parents and children and other family members. The Malaysian law, on the other hand, restricts the right to claim matrimonial property to the spouses only.

\section{The Tunisian Law}

In Tunisia, the so called "Spouses Jointly Shared Property System" has been established by the law 94 for the year 1998 (https://attounissia.blogspot.com/2006/12/blog-post).

The French law classified the matrimonial property as an agreement so that it can be regulated and any disputes related to it can be resolved; that, in turn, makes it a voluntary, rather than mandatory, system. According to some Tunisian researchers, the current form of matrimonial property in the Tunisian law is a voluntary system that spouses agree on when contracting the marriage or even after it; it is independent from the marriage contract and its documents are separate from the marriage documents (Ibid).

\section{Comment and Comparison}

The Tunisian law details the issues related to the matrimonial property like the choice element and the right of dividing the property or claiming it even during the marriage. On the other hand, the Malaysian law restricts the claiming of the matrimonial property to the cases of marriage termination.

\section{Conclusion and Findings}

- The matrimonial property is a contemporary term that has appeared in some Muslim societies and has received the attention of scholars, muftis and jurists.

- Some fatwas have been issued in some countries upholding the right to demand the division of the matrimonial property; such fatwas are based on Shari'ah proofs.

- Laws have been enacted in several countries, including Malaysia, to regulate the ways to acquire the shares of the matrimonial property and to clarify the eligibility reasons to file a matrimonial property claim in pursuit of achieving the interest of the spouses and resolving any related dispute.

- In the Malaysian society, it has been the custom to divide the matrimonial property among the spouses; this custom has represented a strong basis for enforcing it in fiqh, fatwa and judiciary (Beenstock \& Haitovsky, 2004; Chemin, 2009).

Spouses should agree on the details of managing the wealth they acquire jointly and distinguish the share of each of them to avoid any future disputes. 


\section{References}

Academy of the Arabic Language in Cairo., D. T. The Intermediate Lexicon. Ed. Dar Al- Da wah - Egypt.

Ainslie, M. J. (2015). The 2009 Malaysian female circumcision fatwa: state ownership of Islam and the current impasse. In Women's Studies International Forum (Vol. 52, pp. Pergamon. https://doi.org/10.1016/j.wsif.2015.06.015

Al-Hamroni. (2006). Participation in matrimonial property.

Al-Hasakfi. Al-Dar Al-Mukhtar. (2002). Dar Al-Fiker, Beirut: Ed 2.

Al-Qur'an al-Karim.

Beenstock, M., \& Haitovsky, Y. (2004). Does the appointment of judges increase the output of the judiciary?. International Review of Law and Economics, 24(3), 351-369. https://doi.org/10.1016/j.irle.2004.10.006

Chemin, M. (2009). The impact of the judiciary on entrepreneurship: Evaluation of Pakistan's "Access to Justice Programme". Journal of Public Economics, 93(12), 114-125. https://doi.org/10.1016/j.jpubeco.2008.05.005

Fisher, R. P., \& Geiselman, R. E. (2010). The cognitive interview method of conducting police interviews: Eliciting extensive information and promoting therapeutic jurisprudence. International journal of law and psychiatry, 33(5-6), 321-328. https://doi.org/10.1016/j.ijlp.2010.09.004

Ho, P. (2014). The 'credibility thesis' and its application to property rights:(In) secure land tenure, conflict and social welfare in China. Land Use Policy, 40, 13-27. https://doi.org/10.1016/j.landusepol.2013.09.019

Kawalek, A. (2020). A tool for measuring therapeutic jurisprudence values during empirical research. International Journal of Law and Psychiatry, 71, 101581. https://doi.org/10.1016/j.ijlp.2020.101581

Mikhail, J. (2009). Moral grammar and intuitive jurisprudence: A formal model of unconscious moral and legal knowledge. Psychology of learning and motivation, 50, 27-100. https://doi.org/10.1016/S0079-7421(08)00402-7

Mohamed Shahed. (2016). Majallat S1-Shariah Wa al_Qanoon.Malaysia.Vol 3.

Muzkaldy,Omar. Management of money earned between spouses.

Onat, G., \& Beji, N. K. (2012). Effects of infertility on gender differences in marital relationship and quality of life: a case-control study of Turkish couples. European Journal of Obstetrics \& Gynecology and Reproductive Biology, 165(2), 243-248. https://doi.org/10.1016/j.ejogrb.2012.07.033

Oprisan, E., \& Cristea, D. (2012). A few variables of influence in the concept of marital satisfaction. Procedia-social and behavioral sciences, 33, 468-472. https://doi.org/10.1016/j.sbspro.2012.01.165

Panisoara, G., \& Serban, M. (2013). Marital status and work-life balance. Procedia-Social and Behavioral Sciences, 78, 21-25. https://doi.org/10.1016/j.sbspro.2013.04.243

Salman, Noh Ali. (2010). Financial relations between spouses. Ministry of Judgment. Morocco. 2016. Family's Blog.

Sobko, G., Muliar, G., Draliuk, I., Hryhorchuk, M., Holovko, O., \& Lvova, I. (2021). Gaps, conflicts and contradictions regarding measures to ensure the right to a fair trial of the convention for the protection of human rights and fundamental freedoms. Linguistics and Culture Review, 5(S4), 1968-1984. https://doi.org/ 10.21744/lingcure.v5nS4.1856 
Sudama, I. N. (2020). Conflict within tri hita karana's fields: A conceptual review. International Journal of Linguistics, Literature and Culture, 6(6), 8-23. https:/ / doi.org/10.21744/ijllc.v6n6.992

Suryasa, W. (2019). Historical Religion Dynamics: Phenomenon in Bali Island. Journal of Advanced Research in Dynamical and Control Systems, 11(6), 1679-1685. 